\title{
Psychological Health Course Teaching Mode Based on Students' High-order Thinking Ability Development
}

\author{
https://doi.org/10.3991/ijet.v14i04.10111 \\ Zhen Yang \\ Anhui Vocational and Technical College, Hefei, China \\ cbscqq1996@163.com
}

\begin{abstract}
Traditional teaching method cannot really promote students' psychological quality in Psychological Health course teaching. With the purpose of promoting students' high-order thinking ability development, some teaching links (theme importing, question formation, learning participation and evaluation feedback) were adopted to carry out the design and applied research of Psychological Health course teaching mode based on BOPPPS model. The results show that the mode can help students deeply understand and master psychological health knowledge, and mobilize their learning enthusiasm, participation, innovation and subjective initiative. Thus, this mode contributes to promoting students' high-order thinking abilities such as analysis ability, evaluation ability and innovation ability.
\end{abstract}

Keywords-High-order thinking; BOPPPS model; Psychological Health

\section{Introduction}

Under the background of quality-oriented education, the teaching objective of Psychological Health course is to promote undergraduates' psychological health handling capacity, help them establish correct psychological development direction in their future life, gain positive and healthy development after entering the society and form lifelong learning ability [1]. Thus, the public course of Psychological Health is set to impart knowledge for students, and conduct psychological experience and behavior training for students to enhance their psychological health care consciousness and prevention awareness for psychological crisis, make them master psychological health knowledge and gradually establish self-cognition framework, strengthen their interpersonal communication ability and self-regulation ability, and facilitate their allround development [2]. Various universities attach importance to teaching research of Psychological Health education. Different from teaching design of general teaching courses, the teaching design of this course pays more attention to students gaining the experience process of self-cognition and self-development as the subjects, and students' subject participation and creativity. At present, in practical teaching process, large-scale class teaching and low examination threshold are adopted for Psychological Health. The teaching mode is "explanation-mastery-examination". The teaching is centered by the teacher and dominated by expiation. Students' participation degree is 
low, and students' psychological experience process cannot be effectively implemented [3]. They cannot further apply psychological health knowledge, let alone cultivate their innovation ability. Thus, it is extremely urgent to reform the teaching mode and study the teaching design which can really improve students' psychological quality.

\section{State of the Art}

High-order thinking [4] refers to analysis, valuation and creation abilities, and embodies human quality cultivation by education. Thus, it is accepted and praised by numerous education experts, and many research brands derive from it. Richland et al. [5] applied high-order thinking teaching method in mathematical education. They concentrated on mathematics teaching and stressed alignments between the definition of higher order thinking based on psychology and educational objectives as described in U.S. mathematical practice standards. The results show that high-order thinking teaching contributes to enhancing students' learning interest. Moore et al. [6] proposed Malaysian higher education system also needed to focus on students' highorder thinking ability and investigated the application of high-order thinking in science curriculum. Besides, they put forward the changes in the methods to evaluate students mean teachers must teach differently. The focus has changed to development of students' analytical abilities rather than mere recall and understanding. The experiment proved that the reformed teaching is more beneficial to knowledge understanding. Fu [7] carefully analyzed current situation of the deficiency of high-order thinking ability for contemporary college students and indicated that current college students lack thinking knowledge and have severe mindset and poor thinking transfer ability, and that it is urgent to improve their high-order thinking ability. Except students' internal knowledge composition, the influence of talent training mode cannot be ignored. Liu [8] indicated that, teachers need to innovate for teaching mode and enhance design of teaching oriented to high-order thinking ability development. In recent years, BOPPPS teaching model is characterized by clear goal, fine design and strong participation. In combination of timely evaluation, it can be promoted vigorously in design research. Zhang [9] integrated high-order thinking ability training in teaching, expounded teaching mode construction framework and provided reference practice for applying the classroom training mode of high-order thinking.

Through analysis of relevant literatures, we found that the cultivation of students' high-order thinking mainly focuses on science [10], physics, chemistry and other courses, and there is no systematic teaching design scheme which conforms to development of students' psychological health study under network environment. So, highorder thinking and students' psychological health education were innovatively integrated in this study to provide the reference for relevant course reform based on BOPPPS model. 


\section{Psychological Health Teaching Mode with the purpose of promoting students' High-order Thinking Ability Development}

Reflective thinking: high-order thinking is based on "reflective thinking" in this study. The researcher considered reflective thinking [11] is "active, persistent and careful consideration of any belief or assumed knowledge form according to the foundation supporting it and the further conclusion it tends to reach". Typical reflective thinking contains 5 stages or forms with unfixed sequence: question, observation, hypothesis, reasoning and examination. Only the "serious and coherent" thinking can lead to real knowledge. Thus, this study holds that reflective thinking activity "must become an education purpose" and proposes to organize teaching in the form of "learning by doing" through some typical questions. Students explore, do experiments, integrate and accumulate specialized knowledge in the process of solving these questions, and become proficient in the methods of experiment exploration and demonstration so as to cultivate their reflective thinking. The relationship framework between reflective thinking and high-order thinking is shown in Fig.1.

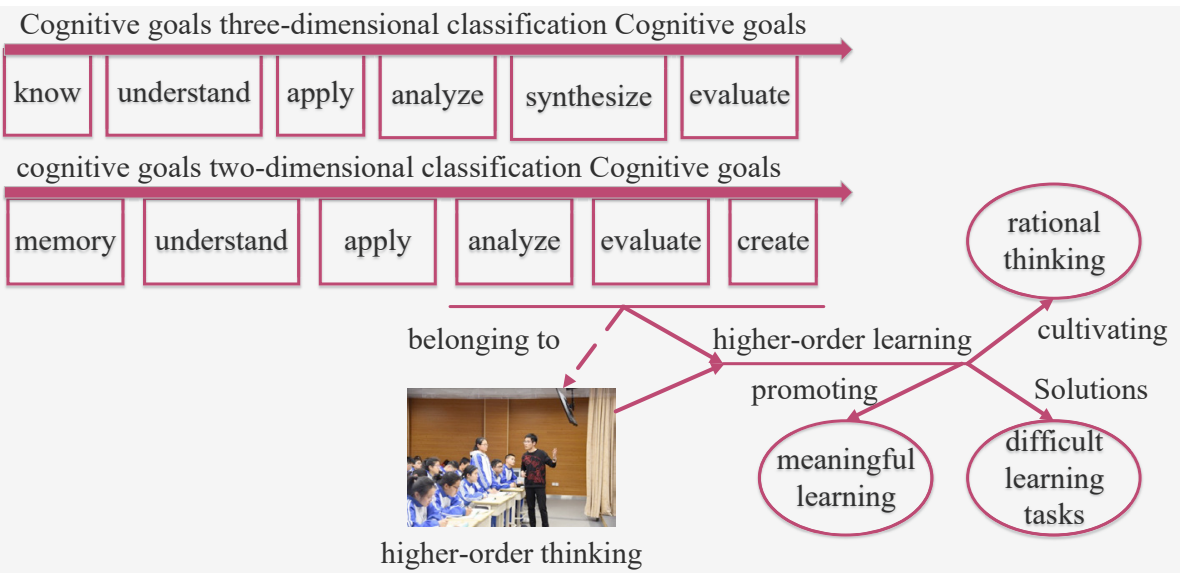

Fig. 1. Relationship framework between reflective thinking and high-order thinking

To achieve the teaching objective, teaching design should be based on course content and relevant teaching theme and combine students' individual features and environmental conditions. Teachers should make full use of principles of teaching and learning, design and plan relevant learning resources for learners and organize a series of learning activities. People are continuously exploring teaching design reform and have developed many teaching design concepts and cases.

In accordance with the theory of Anderson and other experts, schoolwork behavior expressions which should be mastered in human cognitive learning process include memory, understanding, application, analysis, evaluation and creation. Memory, understanding and application are called low-order thinking abilities, while analysis, 
evaluation and creation are called high-order thinking abilities. For Psychological Health course, its teaching objective is to cultivate students' high-order thinking abilities and enhance students' interpersonal communication ability and self-regulation ability. Thus, teaching course reform also should take into account of the objective of high-order thinking ability training to establish course design mode. BOPPPS model [12] takes constructivism and communicative approach as research basis, and emphasizes students' participation in closed-loop teaching process in teaching design. It is an effective teaching design model. According to BOPPPS model, teaching process follows six stages: introduction, objective, pretest, learning participation, posttest, and summarization. The general thought is "introduction - question formation - discussion participation - examination and evaluation". In the implementation process, the whole education mode is student-centered, and fully focuses on learning objective quantification, student participation, learning test and feedback.

Guided by BOPPPS model, the teaching design model of Psychological Health was established in this study, as shown in the following figure, the teaching process is divided into the following stages.

\subsection{Preparatory stage before teaching (introduction stage)}

Teachers select research content according to course arrangement. The events and cases with typical significance in relevant networks and books can be fully used as topics to introduce the theme and choose research topics. Meanwhile, the correlation between topics and selection materials is analyzed to ensure high fit degree. Finally, the teaching objectives which conform to current situation of college students, contribute to college students' life and psychological health development and comply with teaching programme can be gained. Fig. 2 shows teaching design flow chart based on BOPPPS model.

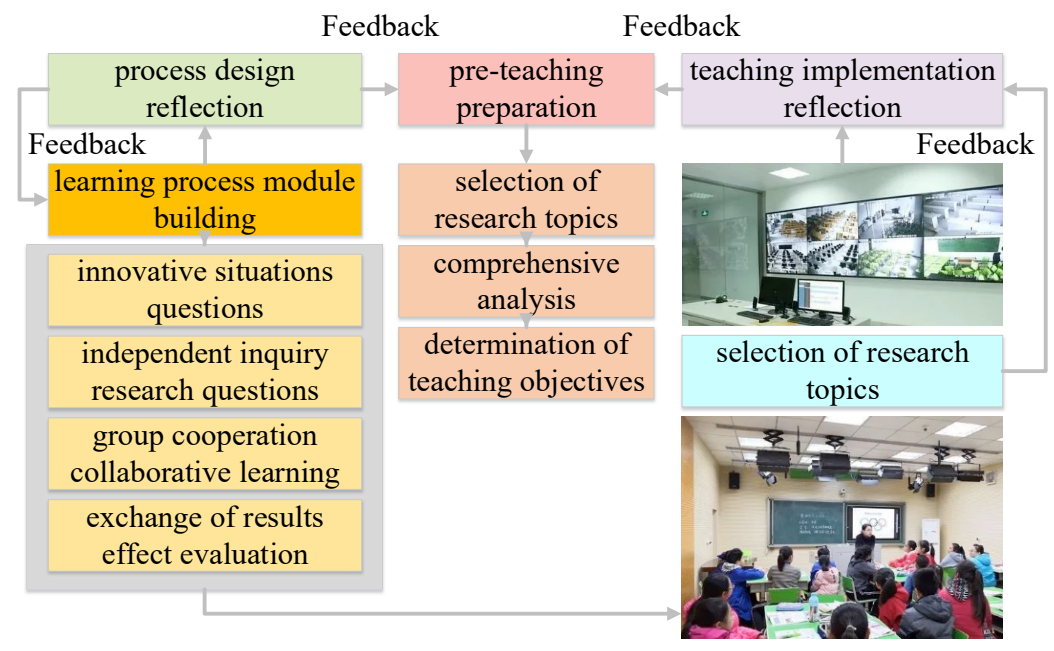

Fig. 2. Teaching design on BOPPPS model 


\subsection{Teaching process module design (question formation - learning participation stage)}

Based on the above teaching mode design thought, teaching mode is planned into four parts, as shown in Fig.3.

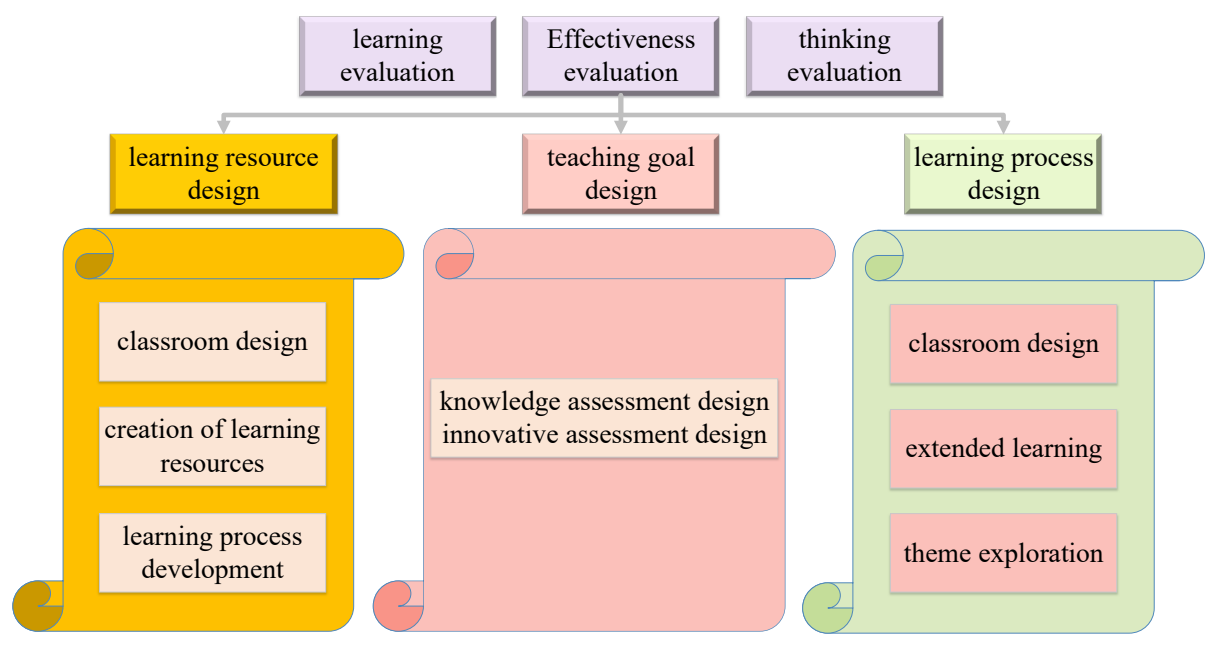

Fig. 3. Teaching process module design diagram based on BOPPPS model

Learning resource design module: This module mainly designs relevant problems of course introduction, integrates relevant learning resources from networks, books and social phenomena, and inputs relevant teaching resources for teaching design program development.

Teaching objective design module: During designing teaching objectives, the contents of examination should be combined for subdivision. According to specific course contents, the contents of examination are divided into knowledge examination content design and innovation examination content design.

Concrete implementation design model of learning process: The course content is introduced through case study, and students are required to further expand learning, summarize and explore the theme in various cases. In this process, students' participation and innovation can be fully mobilized.

Teaching content evaluation design module: This stage corresponds to posttest and summarization steps of BOPPPS model, and also the foundation of process feedback of teaching design. Through examination and evaluation of learning content and in combination of observation and analysis of students' thinking change and development, the results are fed back to other three modules for further modification and improvement so as to gain the optimal teaching design. 


\subsection{Teaching process monitoring stage design (examination and evaluation stage)}

The design embodies teaching implementation is dominated by students and monitored by the teacher. In other words, the teacher should grasp the topic selection and focus on the course outline in students' learning process. At the same time, the teacher should manage students and let them group for cooperative learning. The teacher should be responsible for relevant organization and management work and make the learning groups can learn actively and efficiently. In particular, in the link of exploring learning themes, the teacher should strictly control to prevent the deviation between course content and the outline. For the teaching schedule and direction grasp in theme exploration, this study further analyzed how the teacher and students carried out teaching design for relevant content teaching and learning, as shown in Fig.4. The teacher should grasp group building, guidance and evaluation to make sure students can rationally form groups and carry out relevant learning. Students should make the best of intra-group learning activity for autonomous exploration, discussion and cooperation and gain the optimal learning effect in each group. Meanwhile, students should fully utilize teaching and education platforms and resources to expand learning content, record learning process and achievements in the group activity. Fig.4 shows course theme exploration teaching design based on BOPPPS model.

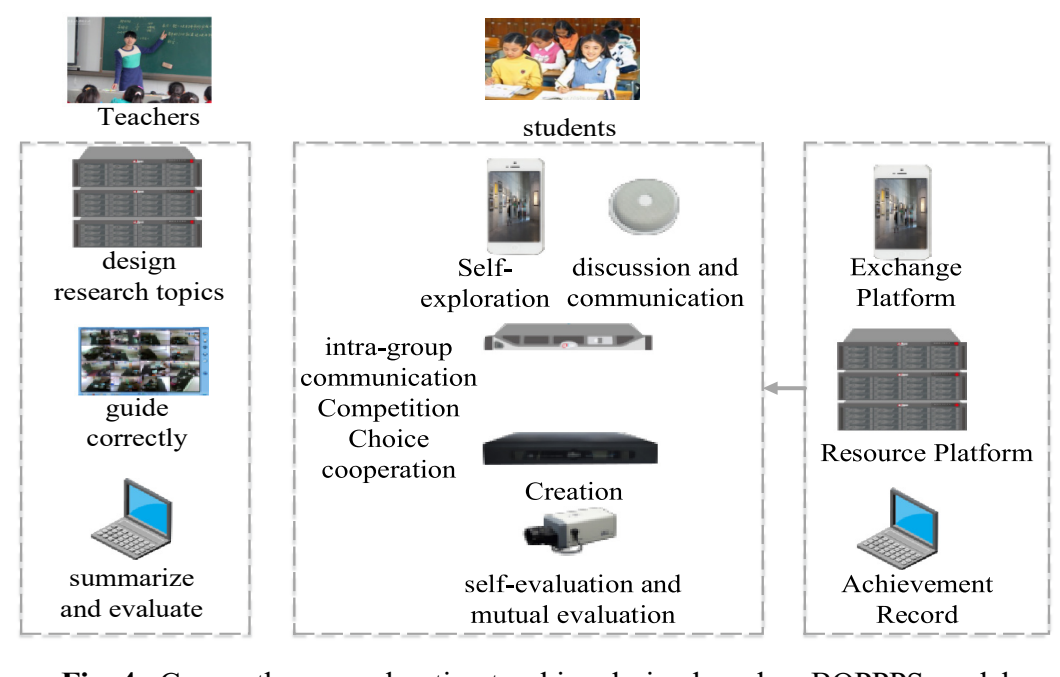

Fig. 4. Course theme exploration teaching design based on BOPPPS model

\section{Teaching Example and Teaching Effect}

\subsection{Teaching example}

Emotional Intelligence of College Students as a special content of college psychological health course has important significance for promoting college students' psy- 
chological quality and learning how to correctly handle emptions and the impacts. According to the focus of low-order thinking knowledge transference and high-order thinking ability training, Psychological Health teaching design was established and the content teaching was conducted by combining the teaching mode in Fig.1 and taking Emotional Intelligence of College Students for example. The detailed process is shown in Table 1. Fig.5 shows the teaching design of Psychological Health with the purpose of developing students' high-order thinking.

Table 1. Teaching mode organization and implementation process of Emotional Intelligence of College Students

\begin{tabular}{|c|c|c|c|}
\hline $\begin{array}{c}\text { Learning } \\
\text { stage }\end{array}$ & Learning steps & Teacher's work & Students' activity \\
\hline Stage I & $\begin{array}{l}\text { Topic introduction } \\
\text { and pretest }\end{array}$ & $\begin{array}{l}\text { 1. Gather tragedy cases caused by the } \\
\text { failure to effectively express emotions } \\
\text { in recent years: personality analysis of } \\
\text { Ma Jiajue; psychological analysis of } \\
\text { college students from rural areas; } \\
\text { 2. Guide students to think how to handle } \\
\text { unhealthy emotions and ideas; } \\
\text { 3. Test students' sensory awareness for } \\
\text { emotions. }\end{array}$ & $\begin{array}{l}\text { 1. Students understand Ma } \\
\text { Jiajue's personality analysis } \\
\text { material; } \\
\text { 2. Students rethink counter- } \\
\text { measures to unhealthy emotions } \\
\text { in life. } \\
\text { 3. Do pretest exercises. }\end{array}$ \\
\hline Stage II & \begin{tabular}{|l|} 
Question for- \\
mation, and \\
students' partici- \\
pation in learning
\end{tabular} & $\begin{array}{l}\text { 1. Give the question for discussion: } \\
\text { how to treat human emotions? How to } \\
\text { correctly master one's own emotion? } \\
\text { 2. Propose the knowledge points about } \\
\text { "emotional intelligence"; } \\
\text { 3. Guide students to build learning } \\
\text { groups; } \\
\text { 4. Guide each group to utilize network } \\
\text { and other resources and combine cam- } \\
\text { pus platform to carry out group learn- } \\
\text { ing, exchange and evaluation; }\end{array}$ & $\begin{array}{l}\text { 1. Students design the research } \\
\text { design for the question and } \\
\text { discuss the research theme; } \\
\text { 2. Students form groups to } \\
\text { integrate, sum up and explore } \\
\text { relevant resources; } \\
\text { 3. Carry out group exchange, } \\
\text { competition, discussion, feed- } \\
\text { back and form the theme of each } \\
\text { group; } \\
\text { 4. Each group conducts theme } \\
\text { evaluation and proposes im- } \\
\text { provement suggestions. }\end{array}$ \\
\hline Stage III & $\begin{array}{l}\text { Achievement } \\
\text { display and evalu- } \\
\text { ation feedback }\end{array}$ & $\begin{array}{l}\text { 1. Check the discussion theme of emo- } \\
\text { tional intelligence of each group, and } \\
\text { carry out discussion and evaluation; } \\
\text { 2. Rethink the teaching process; } \\
\text { 3. Evaluate students' learning process; }\end{array}$ & $\begin{array}{l}\text { 1. Display group discussion } \\
\text { results and confirm the discus- } \\
\text { sion conclusions; } \\
\text { 2. Modify and improve research } \\
\text { theme and conclusion; } \\
\text { 3. Rethink how to control perso- } \\
\text { na emotions in the future. }\end{array}$ \\
\hline
\end{tabular}

For the teaching of concept of emotional intelligence, the teaching content involved is shown in Table 2. Question introduction in the theme and students' participation in theme exploration are fully considered in the table. The questions and guidance closely focus on the course outline, which makes sure the concept of emotional intelligence derives in students' real life, closely follows actual situations of college students, and mobilizes their interest in psychological health and active participation in the activity of psychological health. This can really help students fully utilize what they have learned to regulate their motions and improve their emotion control ability. 
Table 2. Teaching design for the concept of emotional intelligence

\begin{tabular}{|c|c|c|c|}
\hline \multicolumn{4}{|c|}{ Course title: "concept of emotional intelligence" (knowledge) } \\
\hline \multicolumn{4}{|c|}{$\begin{array}{l}\text { Introduction: emotion analysis in the event of Ma Jiajue; mood swing in daily life; } \\
\text { Pretest: (true or false questions) } \\
\text { 1. Emotions cannot be controlled fundamentally. } \\
\text { 2. Emotion control does not belong to intelligence problem, and it entirely depends on personality. } \\
\text { 3. When one is down in spirits, playing games is a good way to control the emotion. }\end{array}$} \\
\hline \multicolumn{4}{|c|}{\begin{tabular}{|c|} 
Theme confirmation process and learning participation: \\
\end{tabular}} \\
\hline Content & Teacher's work & Students' activity & Resource \\
\hline $\begin{array}{l}\text { 1. Which aspects are included in the } \\
\text { concept of emotional intelligence? }\end{array}$ & Ask questions & Think and answer & PPT \\
\hline 2. How to cultivate intelligence? & $\begin{array}{l}\text { Inquire, group, and stress the } \\
\text { key points of discussion }\end{array}$ & $\begin{array}{l}\text { Group discussion, } \\
\text { exchange and share }\end{array}$ & $\begin{array}{l}\text { PPT, A4, } \\
\text { pen }\end{array}$ \\
\hline $\begin{array}{l}\text { 3. The relationship between emotional } \\
\text { intelligence and communication ability }\end{array}$ & Inquire & $\begin{array}{l}\text { Group discussion, } \\
\text { exchange and share }\end{array}$ & $\begin{array}{l}\text { PPT, A4, } \\
\text { pen }\end{array}$ \\
\hline \multicolumn{4}{|c|}{$\begin{array}{l}\text { Summarization, feedback and evaluation: } \\
\text { 1. Cultivate emotional intelligence, and attach importance to family emotional education and emotion } \\
\text { management in social interaction. } \\
\text { 2. Cultivate emotional intelligence and promote communication ability. } \\
\text { 3. Ask students to talk about their feelings about learning of emotional intelligence with one sentence. }\end{array}$} \\
\hline
\end{tabular}

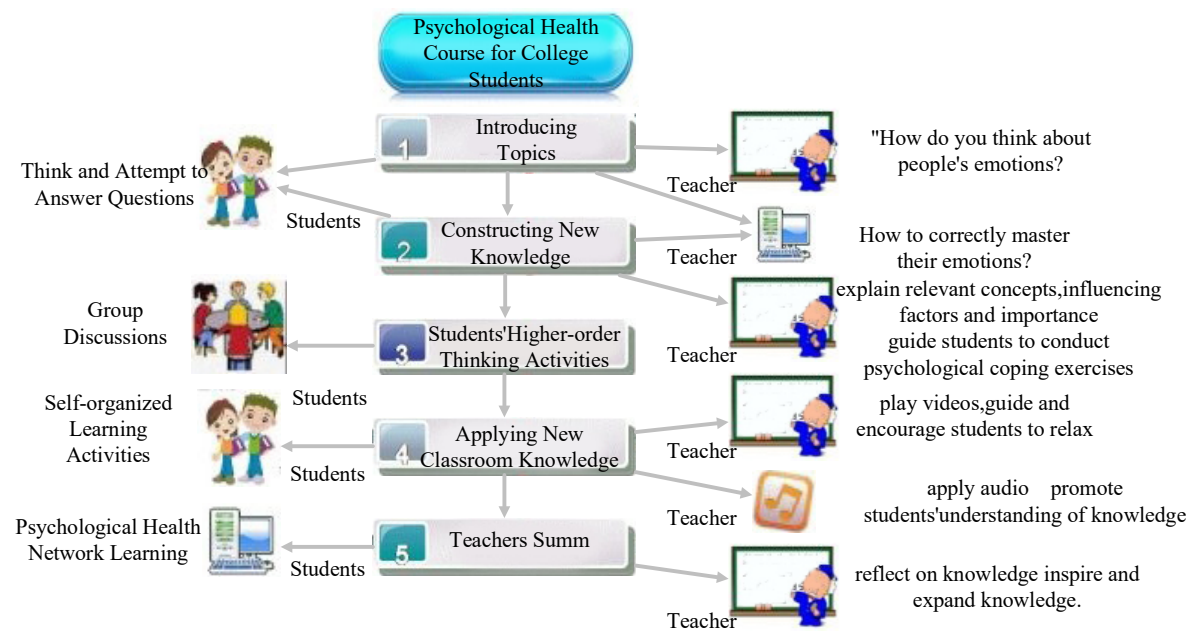

Fig. 5. Teaching design of Psychological Health with the purpose of developing students' high-order thinking I

\subsection{Teaching effect}

Based on the teaching mode of Psychological Health of college students, 98 sophomores from * University were chosen as the objects of study for one-semester Psychological Health teaching. To evaluate the teaching effect of psychological health course - Emotional Intelligence, students' learning process and learning results were recorded according to electronic learning files. The students were classified into 15 groups for research overview of 10 psychological health research themes. Each group was required to form research reports which were input in the electronic learning files. 
After the course ended, final examination was conducted for students, and the test scores were also input in the electronic learning files. Besides, the scores were compared with previous test scores. After the semester ended, interview method was used to know students' experience and evaluation for the actual teaching process.

Records of electronic learning files: Under the similar test difficulty, the scores of final examinations in the past three years and in the research period were compared. It was found that, the score of Psychological Health course with the purpose of promoting students' high-order thinking ability development is higher than that of average score of students for whom traditional teaching method was applied. The average scores were $81.9,82.3$ and 81.6 in 2-15-2017 respectively when traditional teaching mode was used. The average score in 2018 when the teaching mode established in this study was used was 88.4 , obviously higher than that of traditional teaching method. This indicates that the course design of Psychological Health with the purpose of promoting students' high-order thinking ability development obviously facilitates students' learning effect.

Psychological Health records of electronic learning files were collated, including 150 papers about the over view of psychological health research theme. This indicates students' in-depth thinking of psychological health research theme. Such innovation achievement cannot be generated by traditional teaching method. This fully embodies the advantage of such teaching mode in improving students' innovative study.

Evaluation of teaching mode implementation effect with interview method: 40 students were chosen at random for the interview about the experience of psychological health course. The interview content included: Have you ever been interested in psychological health knowledge? After finishing the course, are you interested in psychological health knowledge? Please describe the reason why your interest changes before and after learning the course. Do you like such course teaching mode? Compared with the teaching method in the freshmen year, please evaluate the teaching mode of this semester. What's your attitude to the change of teaching mode? What difficulty did you encounter in group discussion? How did you solve it? Which link do you like best in the learning process? Which link do you think should be improved?

After 40 interview records were summarized, it was found that the interviewees' interest in psychological health knowledge (course) improves greatly. The proportion of students with interest in psychological health knowledge (course) is shown in Fig.4. It can be seen that, about $65 \%$ of students were interested in it. After the new teaching mode was applied, the proportion rises to $90 \%$.

The statistics of students' attitude to teaching mode change is shown in Fig.5. It can be seem that, $90 \%$ of students support the new teaching mode. 


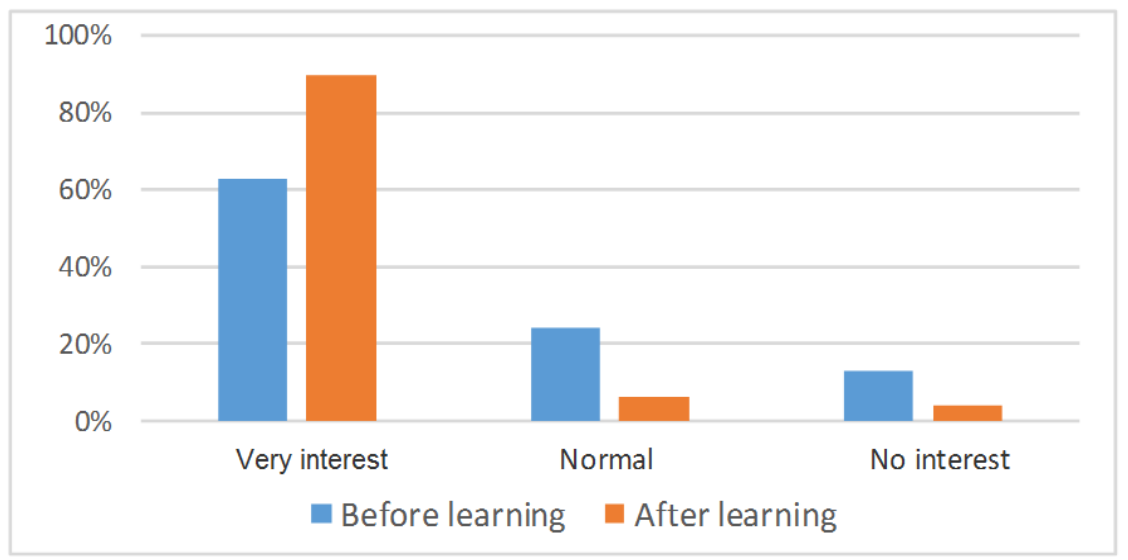

Fig. 6. Proportions of students with interest in psychological health knowledge (course) before and after the implementation of new teaching mode

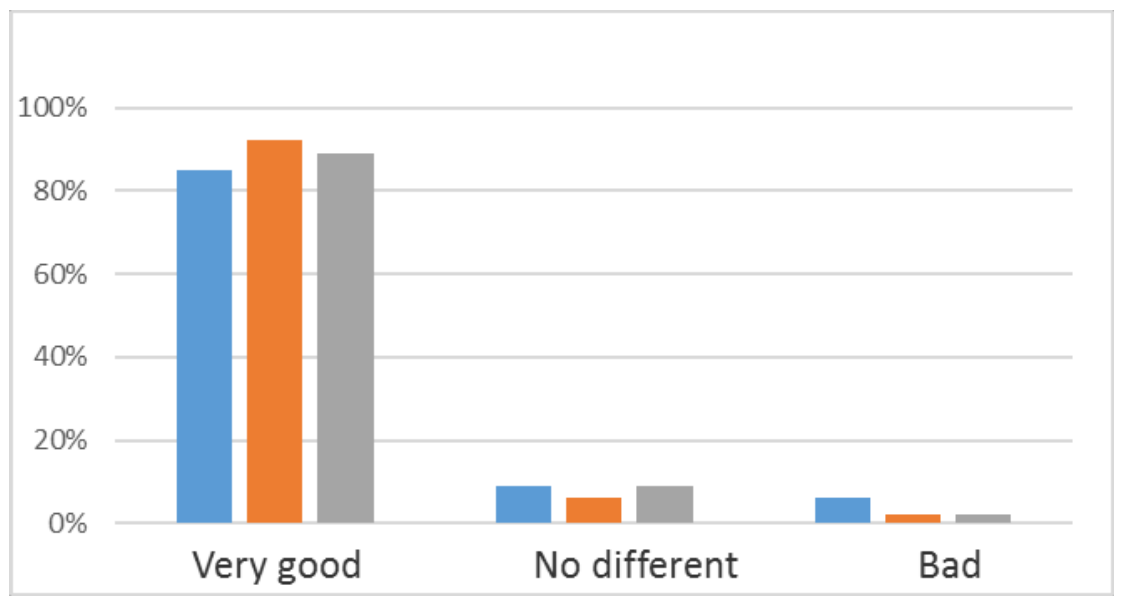

Fig. 7. Students' attitude to teaching mode reform

Seeing from the records of electronic learning files, students' scores of final examination increase, indicating that students' mastery of psychological health knowledge in the new teaching mode is more comprehensive and accurate than that in traditional teaching method. This also reflects the good learning effect. Psychological Health course design teaching mode with the purpose of promoting students' high-order thinking ability development is more beneficial for most students to grasp the knowledge points so that students fully understand psychological health knowledge in practical cases. Question introduction in the teaching mode can arouse students' interest, and the selected cases have certain representativeness and reflect psychological development history of contemporary college students to certain degree. The cases are 
close to students' life. Thus, students can fully and deeply comprehend connotation and denotation of psychological health knowledge.

Psychological Health course design teaching mode with the purpose of promoting students' high-order thinking ability development adds student participation in the four teaching modules. It fully mobilizes students' learning enthusiasm, participation, innovation and subjective initiative through group discussion, expansion, extension, exchange and feedback. In the process of brainstorming, cooperation and sharing, psychological health knowledge has been absorbed and digested by students in the form of explaining profound theories in simple language. In the meantime, participants' thinking perspectives are expanded in the process of solving research overview, and their creation ability also improves in analysis and evaluation process. Campus interactive multimedia teaching platform and education resources are combined to achieve integration and sharing of relevant resources, mobilize learners' original knowledge hierarchy participation and feedback so that they can conform to learning habits in the system of learning new knowledge. Students can fully understand practical application situation of classroom knowledge points and improve their high-order thinking abilities: analysis, evaluation and innovation. Group learning mode improves their teamwork ability, innovation ability and lifelong learning ability. These are the goals of high-order thinking ability development.

\section{Conclusion}

With the guiding principle of promoting students' high-order thinking ability, the teaching mode of Psychological Health for college students was established based on the design thought of BOPPPS, and it was applied in teaching practice. The results show that, the teaching design with the purpose of prompting students' high-order thinking ability greatly optimizes teaching effect, which is mainly reflected in the following aspects:

- The teaching design with the purpose of prompting students' high-order thinking ability depends on case introduction, greatly promotes students' interest in psychological health knowledge and helps them more deeply grasp the connotation of knowledge learned.

- The teaching design with the purpose of prompting students' high-order thinking ability introduces questions by cases, helps students further improve knowledge application in the analysis and evaluation process and contributes to boosting learners' learning ability, innovation ability and other high-order thinking abilities.

- The teaching design adopts group learning mode, mobilizes students' learning enthusiasm, participation, innovation and subjective initiative, enhances their teamwork ability, innovation ability and lifelong learning ability and achieves the objective of high-order thinking ability cultivation. 


\section{Acknowledgement}

This work was supported by Youth Fund Project (2014rwsk01), Key projects in Humanities and Social Sciences (SK2015A698), Key projects in Humanities and Social Sciences (SK2017A0946) and Provincial Quality Project - Large-scale Online Open Course MOOC Project (2017MOOC209).

\section{$7 \quad$ References}

[1] Li, M.L., Nie, J.S., \& Ren, Y.J. Effects of exercise dependence on psychological health of Chinese college students. Psychiatria Danubina, 2015, vol. 27(4), pp. 412-419.

[2] Baghurst, T., Kelley, B.C. An Examination of Stress in College Students over the Course of a Semester. Health Promotion Practice, 2014, vol. 15(3), pp. 438-447. https://doi.org/10. $1177 / 1524839913510316$

[3] Bo, J.Z., Yang, S.Q., Liu, Z.G. Application of Multimedia Teaching in Psychological Health Education of College Students. Advanced Materials Research, 2011, vol. 271-273, pp. 1459-1462. https://doi.org/10.4028/www.scientific.net/AMR.271-273.1459

[4] Pilten, G. Evaluation of the skills of 5th grade primary school students' high-order thinking levels in reading. Procedia-Social and Behavioral Sciences, 2010, vol. 2(2), pp. 13261331. https://doi.org/10.1016/j.sbspro.2010.03.195

[5] Richland, L.E., Begolli, K.N. Analogy and Higher Order Thinking: Learning Mathematics as an Example. Policy Insights from the Behavioral and Brain Sciences, 2016, vol. 3(2), pp. 160-168. https://doi.org/10.1177/2372732216629795

[6] Moore, P.R. Considerations in Teaching Higher Order Thinking Skills to Students with Mild Disabilities. Focus on Exceptional Children, 2017, vol. 25(7), pp. 1-12. https://doi.org/10.17161/fec.v25i7.6885

[7] Fu, H.D., Du, W. Research on Cultivating Strategies of College Students' High-order Thinking Skill. Journal of Changchun University, 2015, vol. 10(5), pp. 110-112.

[8] Liu, Y.H., Liu, X.Y. Designing Teaching for the Development of Higher-order Thinking Ability. Journal of Jiangxi Radio \& TV University, 2013, vol. 20(1), pp. 63-66.

[9] Zhang, Y. Training Strategies of Higher-order Thinking in Political Discipline under the Five-step Guidance Model. Journal of Educational Institute of Jilin Province, 2015, vol. 4(10), pp. 11-12.

[10] Zhang, A.M. The Strategy of Video Design for Micro Course Based on the Construction of Scientific Concepts: A Case Study of "Plant Adaptation to Environment". Journal of Curriculum and Instruction, 2017, vol. 6(2), pp. 65-68.

[11] Kember, D. Determining the level of reflective thinking from students' written journals using a coding scheme based on the work of Mezirow. International Journal of Lifelong Education, 2010, vol. 18(1), pp. 18-30. https://doi.org/10.1080/026013799293928

[12] Zhang, S.J., Liao, X.L., Yu, X.H., et al. The Design of Flipping Classroom Teaching in the Framework of BOPPPS Model. IT Education, 2017, vol. 15(1), pp. 18-22.

\section{Author}

Zhen Yang is an Associate professor in the Anhui Vocational and Technical College, Hefei, China (cbscqq1996@163.com).

Article submitted 09 November 2018. Resubmitted 07 January 2019. Final acceptance 23 January 2019. Final version published as submitted by the author. 